\title{
Development of larvae of the Australian blowfly, Calliphora augur (Diptera: Calliphoridae), at constant temperatures
}

\author{
Donnah M. Day ${ }^{1}$ \\ Nathan J. Butterworth²*, ORCID: 0000-0002-5679-2700, Twitter: @Butterworthbugs \\ Anirudh Tagat ${ }^{3}$, ORCID: 0000-0002-7707-453X, Twitter: @ inhouseeconomist \\ Gregory Markowsky ${ }^{3}$, ORCID: 0000-0003-1656-337X \\ James F. Wallman ${ }^{1,4}$, ORCID: 0000-0003-2504-6075 \\ ${ }^{1}$ Centre for Sustainable Ecosystem Solutions, School of Earth, Atmospheric and Life Sciences, \\ University of Wollongong, NSW 2522, Australia \\ ${ }^{2}$ School of Life Sciences, University of Technology Sydney, Ultimo, NSW 2007, Australia \\ ${ }^{3}$ School of Mathematics, Monash University, VIC 3800, Australia \\ ${ }^{4}$ Faculty of Science, University of Technology Sydney, Ultimo, NSW 2007, Australia \\ E-mail address: nathan.butterworth@uts.edu.au
}

* Corresponding author

Keywords: Forensic entomology, post-mortem interval, prediction interval 


\section{Abstract}

2 Calliphora augur (Diptera: Calliphoridae) is a common carrion-breeding blowfly of forensic, medical 3 and agricultural importance in eastern Australia. Despite this, detailed information on the 4 developmental biology of $C$. augur is lacking. Here, we present the first comprehensive study on the 5 development of all three larval instars of $C$. augur, fed on sheep's liver, at constant temperatures of $615,20,25,30$ and $35^{\circ} \mathrm{C}$. We provide thermal summation models describing instar duration, as well as $795 \%$ prediction intervals for larval length at each constant temperature, enabling the age of larvae of 8 C. augur to be estimated from their developmental stage and their average length. These data provide 9 a basis for the application of this species to forensic investigations. 


\section{Introduction}

32 Forensic entomology is the study of insects as applied to legal issues. It may relate to medicolegal 33 events, especially murders, for the purpose of uncovering information useful to an investigation ${ }^{1}$. This 34 is because decomposing vertebrate remains provide a temporary micro-habitat and food source that is attractive to a variety of insects and other invertebrates ${ }^{2}$. Arthropods constitute a major element of this fauna, with insects, especially flies and their larvae, being the predominant group. Blowflies (Diptera: Calliphoridae) are ubiquitous and are typically the first insects to visit a dead body, often well before it is discovered by humans ${ }^{3}$.

Data on the development of blowflies and other important carrion flies can help provide an estimate of the minimum time since death (or minimum post-mortem interval: mPMI), especially when combined with information on the succession patterns of insects on corpses ${ }^{4}$. Current approaches to age estimation are based on species-specific rates of development such as length, weight, and developmental duration in relation to temperature. While measures based on length and weight are valuable, developmental duration is the most widely used method of age estimation for two primary reasons; 1) because the duration of each stage of larval development (referred to as 'instars') is less variable than larval size (particularly in response to differences in diet) ${ }^{5}$; and 2) because instar stage is not affected by specimen shrinkage during preservation ${ }^{6}$. Once these measurements are obtained for the entire period of larval development, a variety of models can be used to estimate mPMI; including curvilinear regression ${ }^{8}$, isomegalen and isomorphen diagrams ${ }^{9}$, and thermal summation models ${ }^{10,11}$. Of these, the most widely used are thermal summation models that incorporate temperature (usually as degree-hours) and time spent in each developmental stage ${ }^{12}$.

Calliphora augur Fabricius is a common blowfly species found in eastern Australia ${ }^{13}$, the larvae of which are among those most commonly collected from forensic cases, including from inside buildings 14. It is ovoviviparous ${ }^{15}$, and also an agent of myiasis in sheep and other animals ${ }^{16-18}$. Adult females prefer fresh carcasses ${ }^{19}$, but will also larviposit on carcasses in active decomposition (i.e., 10-15 days old ${ }^{20}$. While previous studies have considered the larval development of C. augur ${ }^{16,20-24}$ none have made fine-scale size measurements across a range of constant temperatures, or used thermal

60 summation models to estimate mPMI. This lack of accurate developmental data means that at present,

61 C. augur cannot be used reliably in a forensic context. To ameliorate this, we present the first comprehensive analysis of larval growth at constant temperatures of this important species. Our 
64 observation of larval instar duration. Most importantly, we provide thermal summation models based on instar duration, and calculate prediction intervals based on larval length - for the first time allowing the application of this species to forensic investigations.

\section{Materials and methods}

\section{Fly culture}

70 A culture of $C$. augur was established from adults trapped at Wollongong, New South Wales (34 $25^{\prime}$

$\left.\mathrm{S}, 150^{\circ} 53^{\prime} \mathrm{E}\right)$. Experiments commenced using larvae of the F3 generation and were continued for 11

generations. This culture was refreshed regularly with wild-type $\left(\mathrm{F}_{0}\right)$ individuals from the same source population as above and maintained with mixed ages of females and males. The average fecundity of each female was estimated by separating 20 females and transferring them to $50 \mathrm{~mL}$ specimen pots containing approximately $10 \mathrm{~g}$ of freshly defrosted sheep's liver (defrosted to room temperature immediately prior to experiments). Larvae were counted the following day. Larvae and adults were kept in a temperature-controlled room at $25 \pm 3.5^{\circ} \mathrm{C}$ and ambient humidity, with a $12: 12$ light:dark regime incorporating a 15 minute 'dusk' and 'dawn' transition period of low light. Adult flies were maintained in square plastic cages measuring $330 \mathrm{~mm}$ long, $220 \mathrm{~mm}$ wide and $250 \mathrm{~mm}$ high (external dimensions). The flies in each cage were provided with water and sugar ad libitum, and chopped sheep's liver in a small plastic weigh boat for larviposition as required. Larvae were reared in square white $2 \mathrm{~L}$ plastic containers, measuring $170 \mathrm{~mm}$ wide along each side and $90 \mathrm{~mm}$ deep. Most of the centre of the lid of each container was cut away and replaced with fine mesh to permit ventilation. In each container, larvae were sustained on sheep's liver in the weigh boats placed atop a layer of wheaten chaff approximately $20 \mathrm{~mm}$ deep to enable pupariation. After pupariation, pupae were manually sorted from the chaff and transferred to a cage. Sheep's liver was provided just prior to eclosion to provide females with a constant source of protein for ovary maturation ${ }^{20}$.

\section{Development at constant temperatures}

90 To assess rates of development at constant temperatures, freshly laid larvae were randomly collected 91 from the main culture. Preliminary studies on larval density indicated that some endogenous heat 92 generation occurred with as few as 25 larvae growing on $50 \mathrm{~g}$ of sheep's liver. To ensure that the 93 larvae developed at the ambient temperature being examined, each replicate (a plastic weigh boat

94 containing larvae and liver defrosted to room temperature immediately prior to the experiment) was

95 limited to 10 larvae. The growth period (between 0 and 600 hours) of each replicate of 10 larvae at a 96 particular temperature was chosen by lottery. Between three and six replicates were used for each time 
interval (Supplementary Material 1). These replicates were grown at specific constant temperature regimes $\left(15,20,25,30\right.$ and $35^{\circ} \mathrm{C} \pm 1.0^{\circ} \mathrm{C}$ ) and $60 \pm 5 \%$ relative humidity, in an Axyos (Brisbane, matched the set value, each replicate also contained a temperature logger (iButton; accuracy $\pm 1.0^{\circ} \mathrm{C}$, resolution $0.5{ }^{\circ} \mathrm{C}$; Maxim Integrated Products, Sunnyvale, CA, USA). Since only one cabinet was available, growth at each temperature was studied in turn. Larvae were left undisturbed in darkness in the environmental cabinet until collection, because disturbance can delay pupariation ${ }^{20,24}$. To account for growth rates increasing with temperature, we sampled more frequently at higher temperatures. For $15^{\circ} \mathrm{C}$, sampling was conducted every twenty-four hours, up to a total of 600 hours. For $20^{\circ} \mathrm{C}$, sampling was conducted every six hours, up to a total of 216 hours. For 25,30 and $35^{\circ} \mathrm{C}$ sampling was conducted every four hours, up to a total of 204 hours. The choice of these specific sampling frequencies was guided by the growth curves of $\mathrm{O}^{\prime} \mathrm{Flynn}^{24,25}$, and frequencies were kept relatively high to minimise

\section{Sample collection, handling and preservation}

112 At collection, all larvae were killed and fixed immediately by immersion in boiling water, dried with 113 paper towel and preserved in $80 \% \mathrm{EtOH}$. Larvae were placed into glass vials posteriad to prevent 114 head-curling ${ }^{26}$ and length and instar were recorded.

\section{Larval length measurements}

117 The body lengths of larvae were measured with the aid of a dissecting microscope and Mitutoyo 118 Absolute digimatic digital callipers (Kawasaki, Japan) after the larvae had been in preservative for a 119 minimum of ten days ${ }^{27}$. Body length was measured as the distance, viewed laterally, between the most distal parts of the head and the last abdominal segment. The lengths of pupae were also measured with callipers. The dataset consists of the measurements of the lengths of larvae grown at temperatures of $15^{\circ} \mathrm{C}, 20^{\circ} \mathrm{C}, 25^{\circ} \mathrm{C}, 30^{\circ} \mathrm{C}$, and $35^{\circ} \mathrm{C}$. Since no larvae were measured more than once, the length data for the various time intervals should be regarded as independent.

\section{Larval instar durations}

126 The instar of each larva was also recorded when it was measured as either 1st, 2nd, or 3rd, allowing 127 for the calculation of thermal summation models based on instar duration. We estimated a thermal 128 summation model separately for each stage of development. We estimated two parameters of the 129 thermal summation model given by (DT $=k+t$ D), where DT is the product of D, development 130 duration (in hours) and $\mathrm{T}$, environmental temperature in degrees celsius. The parameters, $\mathrm{k}$ (sum of 
effective temperatures) and $\mathrm{t}$ (lower developmental threshold) were estimated using ordinary least

squares regression as well as reduced major axis regression (RMA) (Ikemoto and Takai, 2000) using

133 the statistical software Stata 16.1. The coefficient on development duration is recovered as $t$ and the

134 constant is recovered as $k$.

\section{Results}

137 On average, gravid females laid $58 \pm 14$ eggs. In total, 3,200 individual larvae (320 replicates of 10 138 larvae) were measured across a range of temperatures $\left(15,20,25,30\right.$ and $35^{\circ} \mathrm{C} \pm 1.0^{\circ} \mathrm{C}$ ) (Figure 1).

139 Regarding the timing of developmental stages, the duration of each instar varied substantially between 140 temperatures (Figure 2). As was expected, the average development time of each instar decreased with 141 increasing temperature up to $30^{\circ} \mathrm{C}$ but increased slightly for third instars at $35^{\circ} \mathrm{C}$. To determine the 142 precise relationships between instar duration and degree-hours, thermal summation models were 143 calculated using ordinary least squares regression (Figure 3) and reduced major axis regression (Figure 144 4). From these models, the sum of effective temperatures $(k)$ and lower developmental threshold $(t)$ 145 were calculated for each instar for both the ordinary least squares regression (Table 1) and reduced major axis regression (Table 2).

148 From our measurements of larval size, we also provide $95 \%$ prediction intervals that can assist in the 149 estimation of age (Supplementary Material 2). Growth curves revealed that first-instar larvae were 150 largest on average when grown at $25^{\circ} \mathrm{C}$. Similarly, second instars were also largest when grown at $15125^{\circ} \mathrm{C}$, but they also displayed a much smaller variation at this temperature compared with the other temperatures examined. Third-instar larvae were largest on average when grown at $20^{\circ} \mathrm{C}$, but were above the overall mean (for third-instars) when growing at $15,20,25$ and $30^{\circ} \mathrm{C}$. The only temperature at which the average length of third instars dropped below their overall mean was at $35^{\circ} \mathrm{C}$. Post-feeding third instars were largest on average when grown at $20^{\circ} \mathrm{C}$.

\section{Discussion}

159 This study provides the first detailed dataset of the development of the Australian carrion-breeding 160 blowfly Calliphora augur. The results we provide here reinforce the previous work done on this 161 species but go substantially further by providing a level of statistical confidence in the application of 162 developmental data in forensic investigations. 


\section{Fecundity}

165 Robust and highly active first-instar larvae of C. augur hatch promptly after deposition, giving this 166 species an ecological advantage over oviparous species for exploiting small, quickly perishable 167 carcasses ${ }^{17}$. Johnston \& Tiegs ${ }^{30}$ reported that $C$. augur is capable of depositing eggs or larvae, with 168 the eggs usually hatching within six hours. In the present study, we noted that $C$. augur will normally 169 deposit living larvae but will also lay soft infertile eggs for some days before normal larviposition 170 occurs - similar to the observations of Mackerras ${ }^{20}$ and O'Flynn ${ }^{25}$. The average number of larvae 171 per female has previously been noted as $50^{20}$ or 58 larvae ${ }^{17}$. Callinan ${ }^{31}$ recorded a range of between

17222.5 and 98.3 larvae per female in a controlled environment and a range of between 0.3 and 45.2 larvae 173 per female in a field environment. The average number of larvae deposited in the present study was $17458 \pm 14$ per gravid female, which is consistent with these previous data.

\section{Development at constant temperatures}

177 The outcomes of some other developmental studies have been limited by a less thorough approach 178 than taken here. For example, Byrd and Butler ${ }^{32}$ noted that their sampling method selected for the 179 fastest growing larvae, which often indicates a shorter period than could otherwise be deduced from 180 normal collection techniques at a crime scene. The influence of size extremes upon variance has also 181 been considered by Wells \& LaMotte ${ }^{7}$. In the present study, we included larvae of all sizes to 182 demonstrate the full range that may be encountered in crime scene samples. Variation in larval body 183 length appeared to decrease steadily from 15 to $30^{\circ} \mathrm{C}$ and then increased again dramatically at $35^{\circ} \mathrm{C}$.

184 The decrease in variation with increasing temperature may relate to a more even growth rate at higher temperatures. However, the subsequent increase in variation at $35^{\circ} \mathrm{C}$ likely reflects the fact that the larvae are reaching their thermal limit, at which point some larvae may begin to suffer from increased heat and oxidative stress, hindering their growth and increasing the perceived variation in size ${ }^{33}$. The variation in overlap of the growth stages, particularly the transitional forms between instars, emphasises the importance of assessing crime scene samples for instar and/or transitional forms, and collecting an adequate number of specimens. While there has been comment on the value of transitional forms ${ }^{34}$, for most blowfly species information on transitional forms is lacking.

The reader will note an interesting feature of the plots related to larval length, namely that the measured 194 lengths increase linearly with time to a certain point, but then begin to decrease after that. This late195 stage reduction in larval length is a result of post-feeding shrinkage that calliphorid larvae undergo 196 after leaving the carcass, prior to pupariation. This post-feeding shrinkage can cause some difficulty 197 in interpreting the age of larvae, because the smaller length of post-feeding larvae makes them appear 
younger. However, this can be solved if investigators record where larvae are collected, as post-feeding larvae will depart the carcass and move into the surrounding substrate. If larvae are collected away from the carcass, it can be presumed that they are in the post-feeding stage and as such, post-feeding confidence intervals should be used to infer their age. Furthermore, post-feeding larvae will rapidly evacuate the crop prior to pupariation, and thus crop dissection can be performed to check for the presence of food particulates. If no food particulates are found, then it can be assumed that the larvae are post-feeding. For a more thorough discussion of this technique see Archer et al. ${ }^{35}$.

While some other previous studies have included data on the development of C. augur ${ }^{16,20-24}$, they were usually conducted as parts of larger projects and provide insufficient detail for inferring an mPMI.

For example, Fuller ${ }^{16}$ only reported the average length of the maggot when full grown $(18 \mathrm{~mm})$, with which our findings concur. Mackerras ${ }^{20}$ referred only to complete development, with 21-22 d recorded for growth in summer conditions in an insectary and $18-20 \mathrm{~d}$ for development in a room at $20^{\circ} \mathrm{C}$. Levot et al. ${ }^{23}$ examined weights of $C$. augur larvae at $27-28^{\circ} \mathrm{C}$ and found the time to reach maximum larval weight to be 65.5 hours. While direct comparisons cannot be drawn with this, we observed that the

213 time to reach maximum larval length at $30^{\circ} \mathrm{C}$ was $72 \mathrm{~h}$. The techniques of Levot et al. ${ }^{23}$ were very

214 different to ours, with a large mass of larvae feeding on excess liver and each sampling event removing 215 some individuals. It is possible that the larvae in their experiment were actually exposed to higher 216 temperatures than the ambient of $27-28^{\circ} \mathrm{C}$ via massing, and that the feeding mass was better able to 217 liquefy the substrate, and therefore grow more quickly, than the larvae in the current study. 218 Comprehensive work by O'Flynn ${ }^{24,25}$ examined larval growth at temperatures between 5 and $45^{\circ} \mathrm{C}$ 219 but did not produce sufficient data for explicit mPMI predictions. At $5^{\circ} \mathrm{C}$, the minimum period from 220 larviposition to commencement of wandering was $54 \mathrm{~d}$; some larvae survived for $110 \mathrm{~d}$ but none 221 pupated.

\section{Larval temperature preference}

224 It is well known that blowfly larvae show species-specific temperature preferences, which are 225 behavioural adaptations that maximise developmental rate, growth quality, and survival 36. 226 Examination of instar size and duration across temperatures in our study indicates that the larvae of $C$. augur also experience optimal growth at specific temperatures related to their growth stage. In terms of size, the only temperature at which the average length of third instars dropped below their overall mean was at $35^{\circ} \mathrm{C}$, and post-feeding third instars were largest on average when grown at $20^{\circ} \mathrm{C}$.

230 Regarding instar duration, the shortest developmental times were observed at $35^{\circ} \mathrm{C}$ for first and second 231 instars, and at $30^{\circ} \mathrm{C}$ for third instars - but the most substantial reduction in development time for all 
instars was seen between 15 and $20^{\circ} \mathrm{C}$. In addition, it appears that the lower developmental threshold

$233(t)$ for $C$. augur lies between 11 and $20^{\circ} \mathrm{C}$ (depending on instar). Altogether, this suggests that the

234 development of $C$. augur is likely optimal around $30^{\circ} \mathrm{C}$, but suffers at temperatures above this.

235 Importantly, the species may be capable of completing development at temperatures as low as $11^{\circ} \mathrm{C}$

236 and can comfortably complete development at $20^{\circ} \mathrm{C}$ - which is in line with this species remaining

237 active during the Australian winter.

\section{Environmental conditions and larval growth}

240 Importantly, it is well established that the growth and survival of blowfly larvae is dependent upon 241 their food source. For example, studies on Calliphora vicina and Calliphora vomitoria have shown 242 substantial differences in larval growth between mixed minced meats and beef liver ${ }^{37}$ and there are 243 differences in larval growth between livestock and human tissue ${ }^{38}$. While the measurements we 244 provide here are based on $C$. augur fed on sheep's liver, these data are assumed to apply to the 245 equivalent growth in human bodies - an assumption that holds true for comparisons between $C$. vicina 246 larvae fed on porcine and human tissue ${ }^{5}$. Nevertheless, this assumption remains to be tested with $C$. 247 augur, and age calculations based on data from animal tissue may lead to inaccurate mPMI estimates $248 \quad 37,38$. For most forensically important species, including C. augur, there remains a pressing need for 249 broad-scale studies that compare growth rates between a range of tissues from different animal taxa ${ }^{37,5}$.

251 In addition to this, it is important to note that the larvae reared in our developmental experiments were 252 kept in darkness without a day/night light cycle. It is well known that photoperiod can influence larval 253 growth rate and development ${ }^{39,40}$, and as such, our data may not reflect the developmental rate that 254 would occur under a 12:12 day night cycle. Nevertheless, very few studies have explored the effect of 255 complete darkness on insect larval development, so it is unclear to what extent this would influence 256 developmental rate. In addition, many forensic cases concerning entomology involve corpses found in 257 secluded places such as abandoned buildings, houses, and basements ${ }^{41}$ which are often exposed to very 258 low levels of light (and in certain cases complete darkness). Future studies of C. augur development, 259 and indeed blowflies more generally, will benefit from investigating how larval development differs 260 under a range of lighting conditions (including full darkness, artificial light, and natural light).

\section{Conclusions}

263 Overall, we provide prediction intervals based on larval length and thermal summation models based 264 on instar duration, at a range of constant temperatures. This comprehensive dataset forms a basis for 
estimating the age of larvae of $C$. augur, for the first time enabling the application of this species to forensic investigations.

\section{Acknowledgements}

269 We thank the University of Wollongong for financial assistance with this study.

\section{Disclosure statement}

272 The authors have no conflict of interest to declare.

\section{Data availability statement}

275 All data has been made available as supplementary material.

\section{References}

279 1. Catts EP \& Goff ML (1992) Forensic entomology in criminal investigations. Annual Review $280 \quad$ Entomology 37: 253-272.

2. Smith KGV (1986) A manual of forensic entomology. British Museum (Natural History), London

3. Greenberg B (1991) Flies as forensic indicators. Journal of Medical Entomology 28: 565-577.

4. Sharma R, Garg RK, Gaur JR (2015) Various methods for the estimation of the post-mortem interval from Calliphoridae: A review. Egyptian Journal of Forensic Sciences 5:1-12.

5. Bernhardt V, Schomerus C, Verhoff MA, Amendt J (2017) Of pigs and men - comparing the development of Calliphora vicina (Diptera: Calliphoridae) on human and porcine tissue. International Journal of Legal Medicine 131:847-853.

6. Harvey ML, Gasz NE, Voss SC (2016) Entomology-based methods for estimation of postmortem interval. Research and Reports in Forensic Medical Sciences 6:1-9.

7. Wells JD \& LaMotte LR (1995) Estimating maggot age from weight using inverse prediction. Journal of Forensic Sciences 40: 585-590.

8. Ullyett GC (1950) Competition for food and allied phenomena in sheep-blowfly populations. Philosophical Transactions of the Royal Society London B: Biological Sciences. 234:77-174

9. Grassberger M \& Reiter C (2001) Effect of temperature on Lucilia sericata (Diptera: Calliphoridae) development with special reference to the isomegalen- and iosmorphen-diagram. Forensic Science International 120: 32-36. 
bioRxiv preprint doi: https://doi.org/10.1101/2021.01.19.427229; this version posted April 11 2021. The copyright holder for this preprint (which was not certified by peer review) is the author/funder, who has granted bioRxiv a license to display the preprint in perpetuity. It is made available under aCC-BY-ND 4.0 International license.

10. Jakubec $P$ (2016) Thermal summation model and instar determination of all developmental stages of necrophagous beetle, Sciodrepoides watsoni (Spence) (Coleoptera: Leiodidae: Cholevinae). PeerJ 4:e1944

11. Richards CS, Crous KL \& Villet MH (2009) Models of development for blowfly sister species Chrysomya chloropyga and Chrysomya putoria. Medical and Veterinary Entomology 23: 56-61.

12. Harvey, ML, Gasz NE, Voss SC (2016) Entomology-based methods for estimation of postmortem interval. Research and Reports in Forensic Medical Science 6:1-9.

13. Wallman JF \& Adams M (1997) Molecular systematics of Australian carrion-breeding blowflies of the genus Calliphora (Diptera: Calliphoridae). Aust Journal of Zoology 45: 337-356.

14. Levot G (2003) Insect fauna used to estimate the post-mortem interval of deceased persons. General and Applied Entomology 32: 31-39.

15. Meier R, Kotrba M \& Ferrar P (1999) Ovoviviparity and viviparity in the Diptera. Biological Reviews 74: 199-258.

16. Fuller ME (1934) The Insect Inhabitants of Carrion: A Study in Animal Ecology. Bulletin of the Council for Scientific and Industrial Research 82: 1-63.

17. Norris KR (1959) The ecology of sheep blowflies in Australia. Monographiae Biologicae: Biogeography and Ecology in Australia (ed. by A Keast, RL Crocker \& CS Christian) Junk, The Hague, The Netherlands, pp. 514-544.

18. Lee DJ (1968) Human myiasis in Australia. Medical Journal of Australia 1: 170-173.

19. Monzu N (1977) Coexistence of Carrion Breeding Calliphoridae (Diptera) in Western Australia. $\mathrm{PhD}$ Thesis, University of Western Australia, Crawley, WA, Australia.

20. Dawson BM, Barton PS, Wallman JF (2020) Contrasting insect activity and decomposition of pigs and humans in an Australian environment: A preliminary study. Forensic Science International 316:110515

21. Johnston TH \& Hardy GH (1923) Observations regarding the life-cycle of certain Australian blowflies. Proceedings of the Royal Society of Queensland 35: 21-42.

22. Mackerras MJ \& Freney MR (1933) Observations on the nutrition of maggots of Australian blowflies. Journal of Experimental Biology 10: 237-246.

23. Levot GW, Brown KR \& Shipp E (1979) Larval growth of some calliphorid and sarcophagid Diptera. Bulletin of Entomological Research 69: 469-475.

24. O'Flynn MA (1983) The succession and rate of development of blowflies in carrion in southern Queensland and the application of these data to forensic entomology. Journal of the Australian Entomological Society 22: 137-148. 
25. O'Flynn MA (1980) Studies on Blowflies and Related Flies from Queensland. PhD Thesis, University of Queensland, Brisbane, Qld, Australia.

26. Day DM \& Wallman JF (2006) Width as an alternative measurement to length for postmortem interval estimations from Calliphora augur (Diptera: Calliphoridae) larvae. Forensic Science International 159: 158-167.

27. Day DM \& Wallman JF (2008) Effect of preservative solutions on preservation of Calliphora augur and Lucilia cuprina larvae (Diptera: Calliphoridae) with implications for post-mortem interval estimates. Forensic Science International 179: 1-10.

28. Geisser S \& Johnson W (2006) Modes of Parametric Statistical Inference, Wiley, New York, NY, USA.

29. Lumley T, Diehr P, Emerson S, Chen L (2002) The importance of the normality assumption in large public health datasets. Annual Review of Public Health 23:151-169

30. Johnston TH \& Tiegs OW (1922) Notes on the biology of some of the more common Queensland muscoid flies. Proceedings of the Royal Society of Queensland 34: 77-104.

31. Callinan APL (1980) Aspects of the ecology of Calliphora augur (Fabricus) (Diptera: Calliphoridae), a native Australian blowfly. Australian Journal of Zoology 28:679-684

32. Byrd JH \& Butler JF (1998) Effects of temperature on Sarcophaga haemorrhoidalis (Diptera: Sarcophagidae) development. Journal of Medical Entomology 35: 694-698.

33. Rivers DB, Thompson C, Brogan R (2011) Physiological trade-offs of forming maggot masses by necrophagous flies on vertebrate carrion. Bulletin of Entomological Research 101:599-611.

34. Catts EP (1991) Analyzing entomological data. Entomology and Death: a procedural guide (ed. by EP Catts \& NH Haskell) Joyce's Print Shop Inc, Clemson, SC, USA, pp. 124-137.

35. Archer MS, Jones SD, Wallman JF (2017) Delayed reception of live blowfly (Calliphora vicina and Chrysomya rufifacies) larval samples: implications for minimum postmortem interval estimates. Forensic Sciences Research 3:27-39.

36. Aubernon C, Boulay J, Hédouin V, Charabidzé D (2016) Thermoregulation in gregarious dipteran larvae: evidence of species-specific temperature selection. Entomologia Experimentalis et Applicata 160:101-108.

37. Neideregger S, Wartenberg N, Spiess R, Mall G (2013) Influence of food substrates on the development of the blowflies Calliphora vicina and Calliphora vomitoria (Diptera, Calliphoridae). Parasitology Research 112:2847-2853.

38. Wallman JF \& Archer MS (2020) The application of insects to the estimation of the time since death. In J Hayman \& M Oxenham, Estimation of the Time Since Death (pp. 57-74). Elsevier, London, UK 
39. Saunders DS (1972) Circadian control of larval growth rate in Sarcophaga argyrostoma. Proceedings of the National Academy of Science USA 69:2738-2740.

40. Nabity PD, Higley LG, Heng-Moss TM (2007) Light-induced variability in development of forensically important blow fly Phormia regina (Diptera: Calliphoridae). Journal of Medical Entomology 44:351-358

41. Michalski M, Nadolski J (2018) Thermal conditions in selected urban and semi-natural habitats, 371 
Table 1. Summary of development constants for $C$. augur for three developmental stages, based on ordinary least squares regression.

411 Sum of effective temperatures $(k)$ and lower developmental threshold $(t)$ shown as means with

standard errors (coefficient of determination $\left(\mathrm{R}^{2}\right)$ and degrees of freedom (Df) and p-values are provided).

\begin{tabular}{rlrrrll} 
Stage & Temperature range & \multicolumn{1}{l}{$\mathbf{R}^{\mathbf{2}}$} & \multicolumn{1}{c}{ Df } & p-value & $\boldsymbol{k}( \pm \boldsymbol{S E})$ & $\boldsymbol{t}( \pm \boldsymbol{S E})$ \\
\hline 1 & $15-35$ & 0.9045 & 526 & $<0.001$ & $19.5135 \pm 2.5992$ & $19.202 \pm 0.2717$ \\
2 & $15-35$ & 0.7744 & 586 & $<0.001$ & $361.332 \pm 10.889$ & $11.543 \pm 0.257$ \\
3 & $15-35$ & 0.7379 & 2068 & $<0.001$ & $1072.928 \pm 27.335$ & $13.283 \pm 0.174$ \\
\hline
\end{tabular}

Table 2. Summary of development constants for $C$. augur for three developmental stages based threshold $(t)$ shown as means. Coefficient of determination $\left(\mathrm{R}^{2}\right)$ and degrees of freedom (Df) and $\mathrm{p}-$ values are provided.

\begin{tabular}{rlrrrll}
\hline Stage & Temperature range & $\mathbf{R}^{2}$ & Df & p-value & $\boldsymbol{k}$ & $\boldsymbol{t}$ \\
\hline 1 & $15-35$ & 0.951 & 526 & $<0.001$ & 14.216 & 20.188 \\
2 & $15-35$ & 0.7744 & 586 & $<0.001$ & 303.242 & 13.114 \\
3 & $15-35$ & 0.7379 & 2068 & $<0.001$ & 792.078 & 15.462 \\
\hline
\end{tabular}


bioRxiv preprint doi: https://doi.org/10.1101/2021.01.19.427229; this version posted April 11, 2021. The copyright holder for this preprint (which was not certified by peer review) is the author/funder, who has granted bioRxiv a license to display the preprint in perpetuity. It is made available under aCC-BY-ND 4.0 International license.
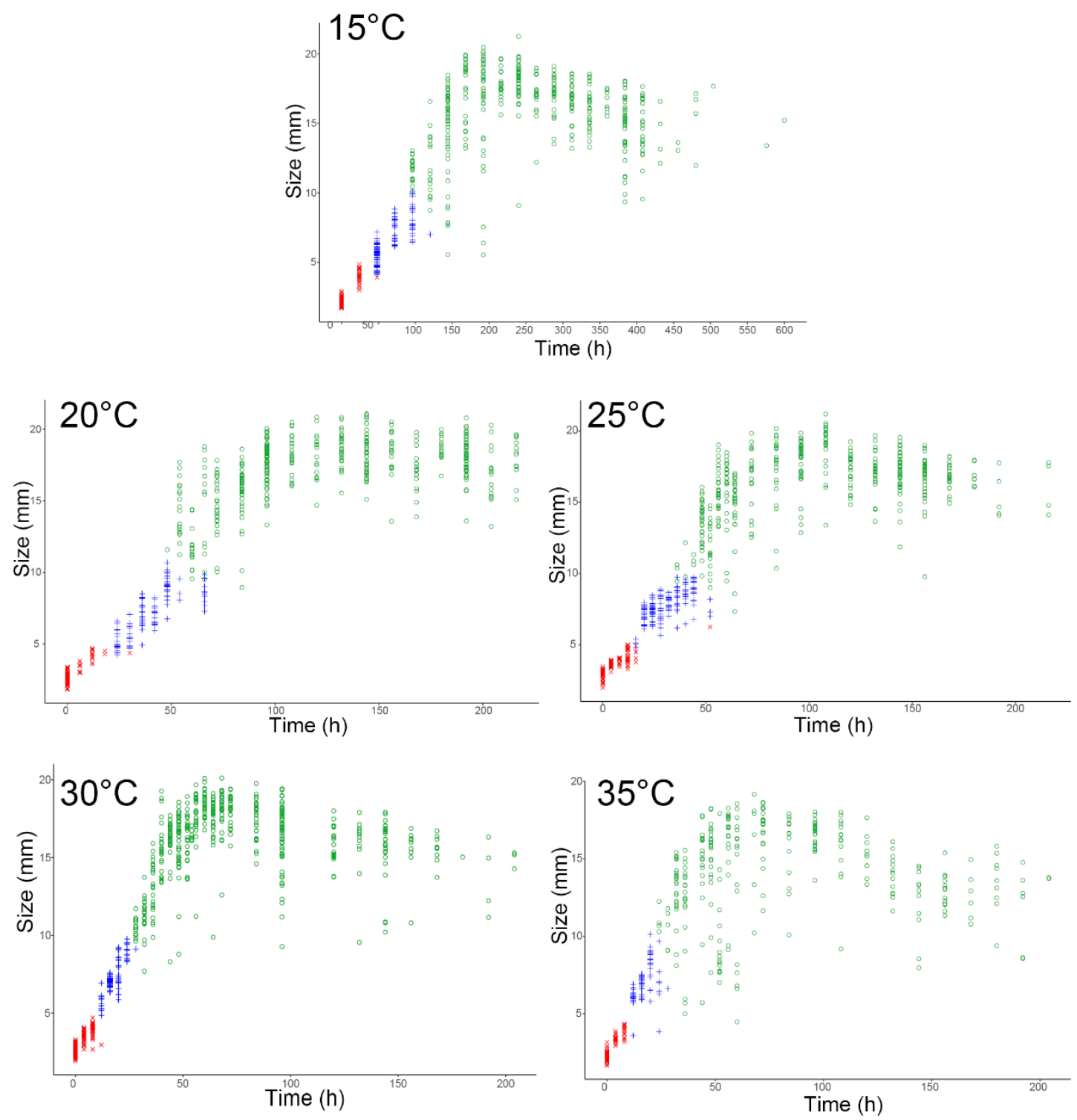

Figure 1. Growth curves of Calliphora augur larvae at constant temperatures. Data points represent individual larvae at each treatment time. First-instar larvae are represented by the $\times$, second-instar by the + , and third-instar by the o. The first plot $\left(15^{\circ} \mathrm{C}\right)$ has a different scale on the $\mathrm{x}$-axis. 
492

493

494

495

496

497

498

499

500

501

502

503

504

505

506

507

508

509

510

511

512

513

514

515

516

517

518

519

520

521

522

523

524

525

526

527

528

529

530

531

532

533

534

535

536

537

538

539

540

541

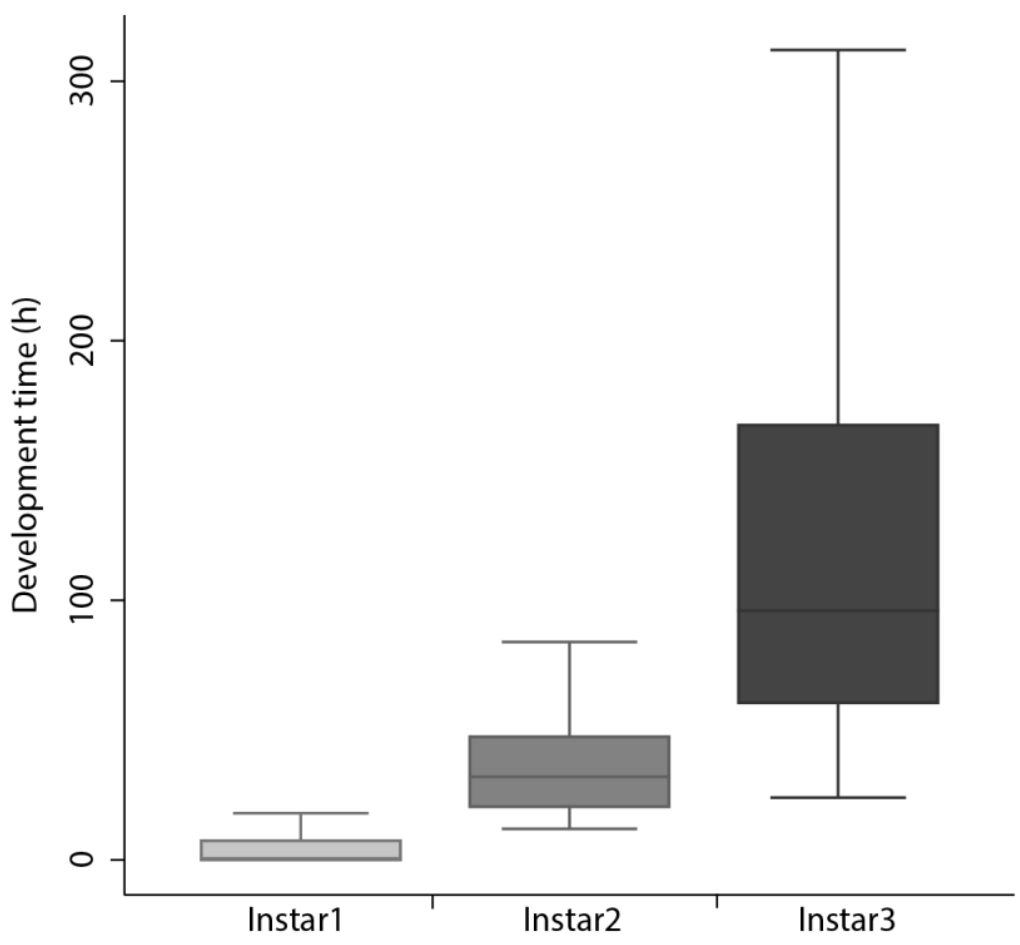

Figure 2. Observed range of instar durations of Calliphora augur larvae over five experimental treatments $\left(15,20,25,30,35^{\circ} \mathrm{C}\right)$. The horizontal lines within boxes represent median values. The upper and lower boxes indicate $75^{\text {th }}$ and $25^{\text {th }}$ percentiles.

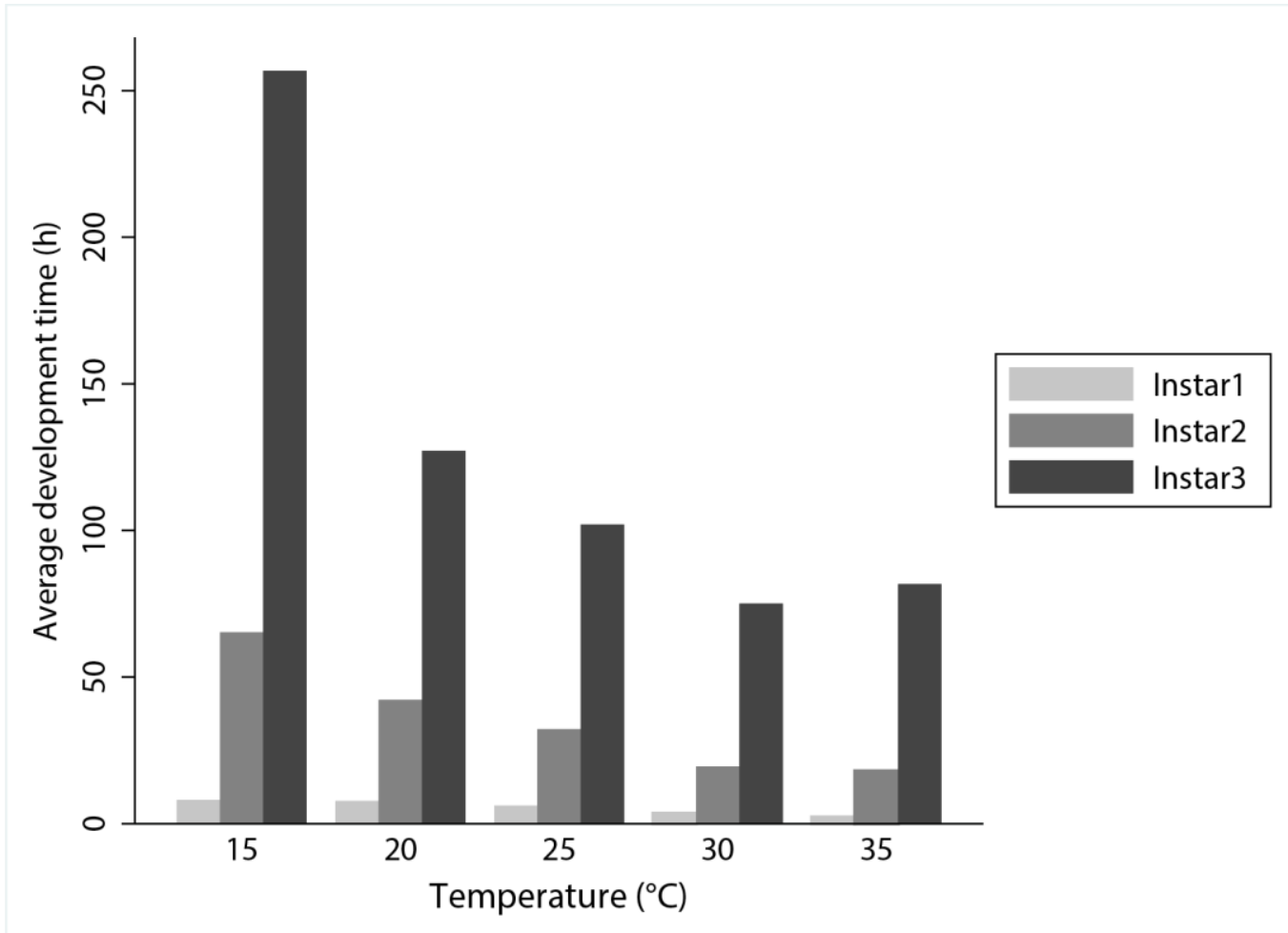

Figure 3. Bar plots of mean instar duration (hours) of all three instars of Calliphora augur across five experimental treatments $\left(15,20,25,30,35^{\circ} \mathrm{C}\right)$. 
bioRxiv preprint doi: https://doi.org/10.1101/2021.01.19.427229; this version posted April 11, 2021. The copyright holder for this preprint (which was not certified by peer review) is the author/funder, who has granted bioRxiv a license to display the preprint in perpetuity. It is made available under ACC-BY-ND 4.0 International license.

542

543

544

545

546

547

548

549

550

551

552

553

554

555

556

557

558

559

560

561

562

563

564

565

566

567

568

569

570

571

572

573

574

575

576

577

578

579

580

581

582

583

584

585

586

587

588

589

590

591
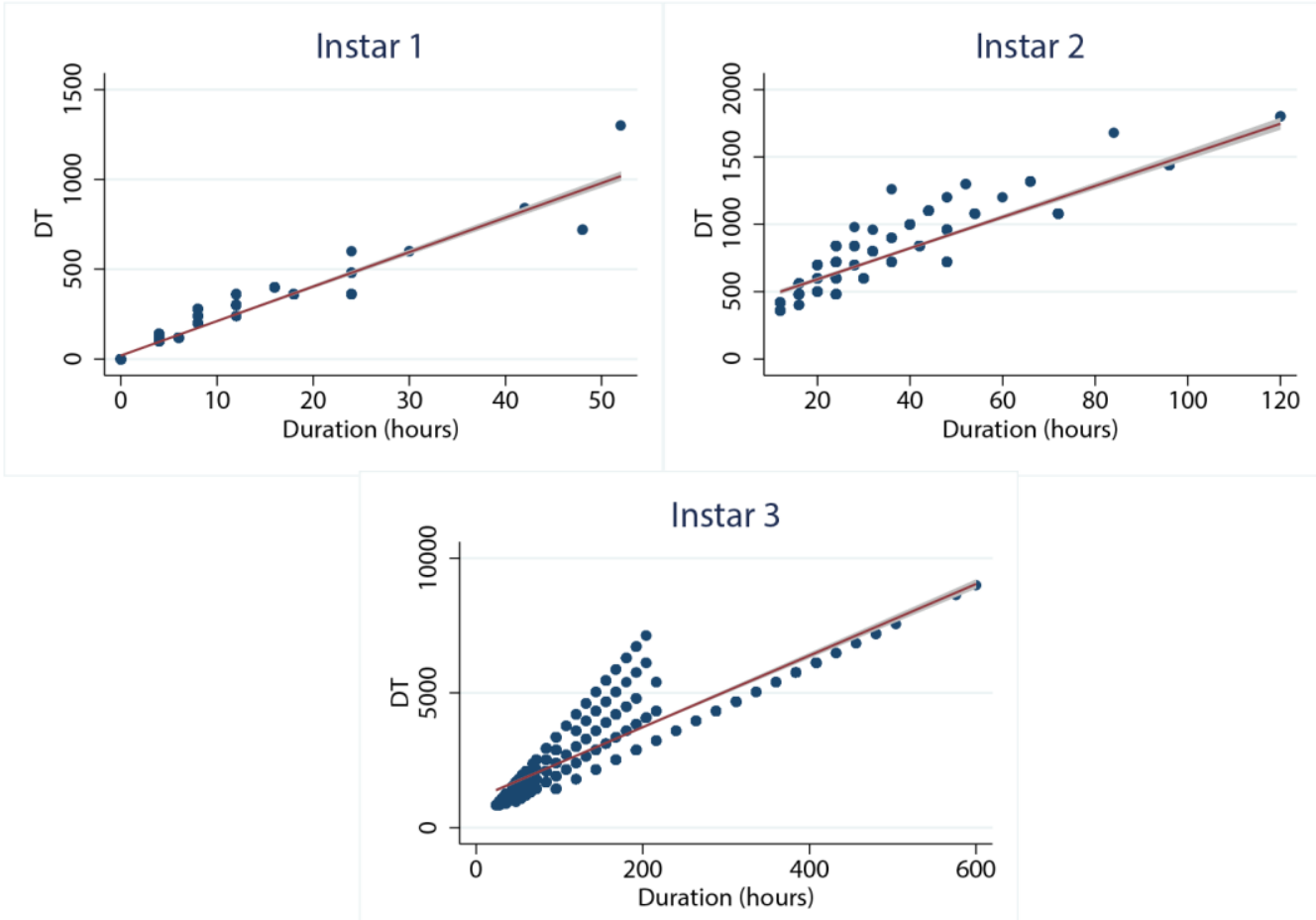

Figure 4. Ordinary least squares regression for the duration of development of each instar stage of Calliphora augur. DT represents the time in hours to reach the stage multiplied by the constant rearing temperature. 
bioRxiv preprint doi: https://doi.org/10.1101/2021.01.19.427229; this version posted April 11, 2021. The copyright holder for this preprint (which was not certified by peer review) is the author/funder, who has granted bioRxiv a license to display the preprint in perpetuity. It is made available under aCC-BY-ND 4.0 International license.

592

593

594

595

596

597

598

599

600

601

602

603

604

605

606

607

608

609

610

611

612

613

614

615
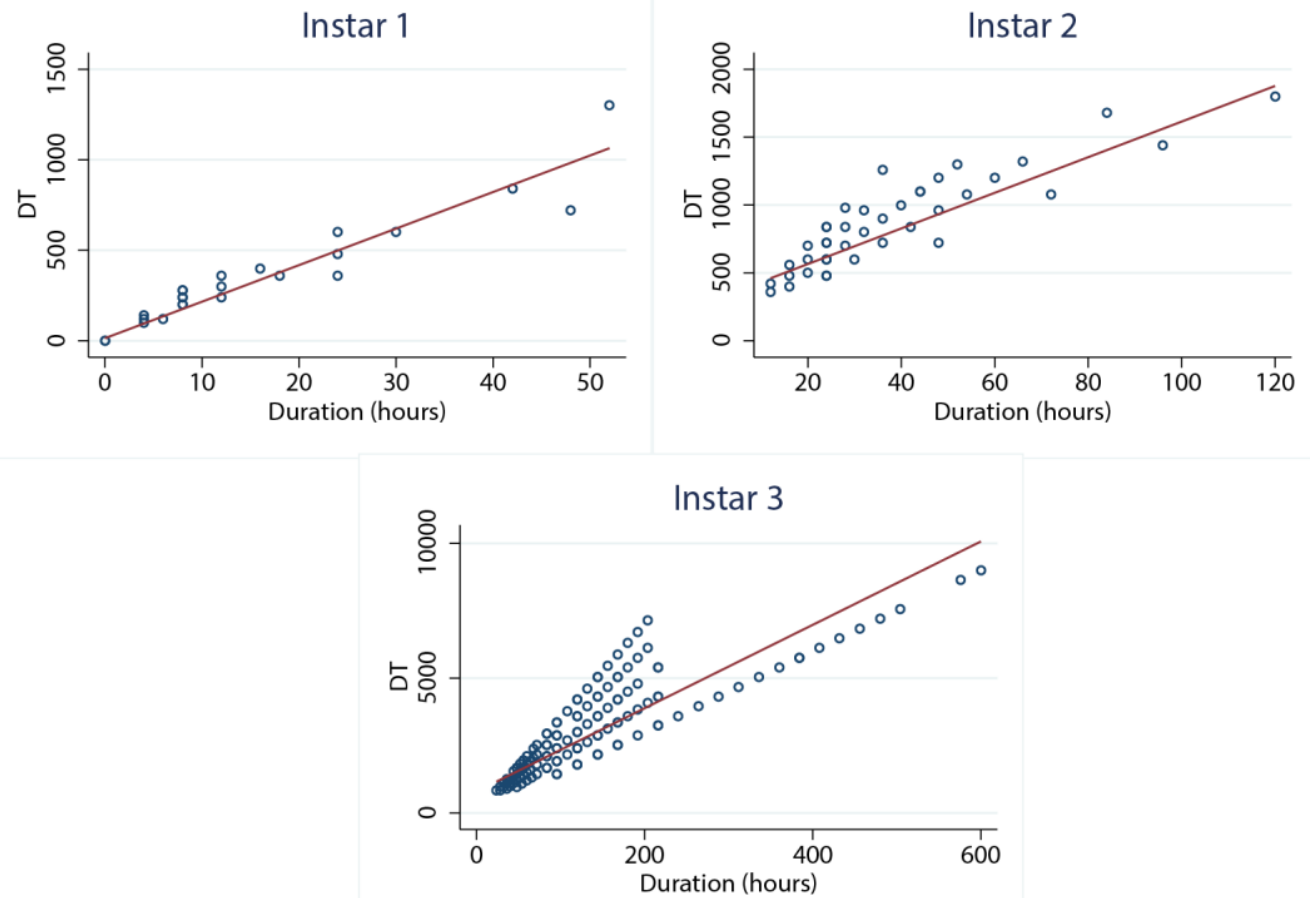

Figure 5. Reduced major axis regressions for the duration of development of each instar stage of Calliphora augur. DT represents the time in hours to reach the stage multiplied by the constant rearing temperature. 